\title{
The Effect of Protoscoleces Treated With Direct Electrical Current on the Cellular Immune Response in Mice Infected With Secondary Hydatid Disease
}

\author{
Sadam Salim Yaseen \\ Department of Biology/ College of Education \\ University of Mosul
}

Received
$\uparrow ৭ / 05 / 2008$

Accepted

$08 / 01 / 2009$

\begin{abstract}
الخلاصة

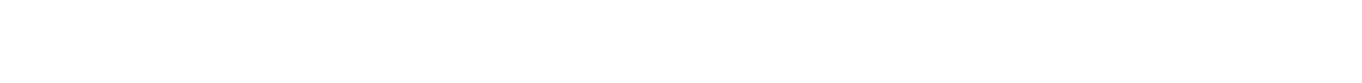

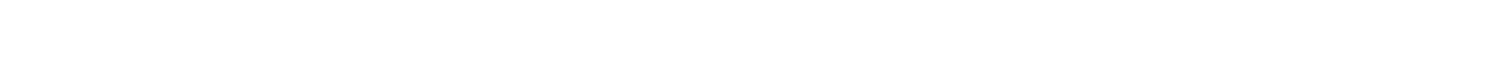

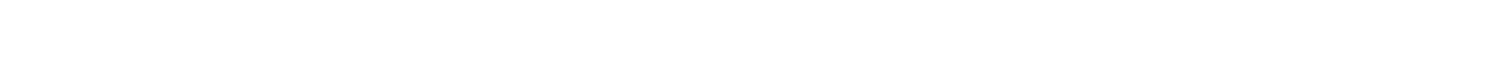

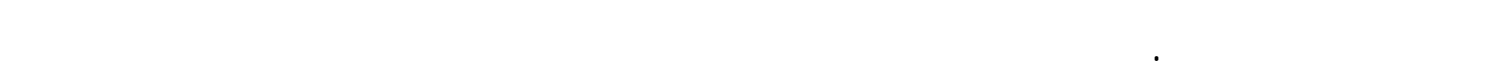

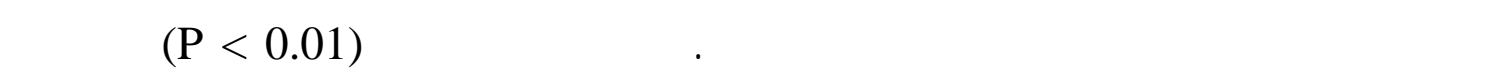

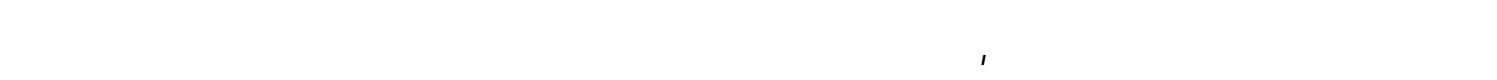
O,VV

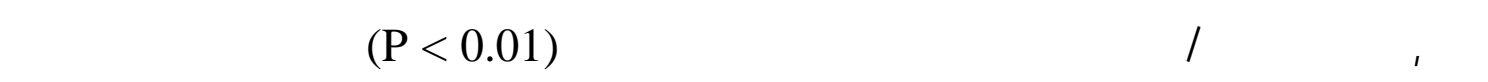

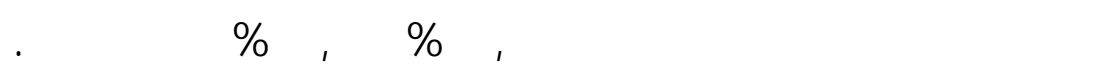

\begin{abstract}
This study investigates the cellular immune response in BALB/c mice immunized with protoscoleces (PSC) of Echinococcus granulosus of sheep origin, treated with direct electrical current, depending on some immunological criteria including delayed type hypersensitivity (DTH) and mitotic activity of cells obtained from lymphoid organs, spleen and bone marrow. The results revealed an increase in cellular immune response in immunized groups compared with the control group infected for 3 months.
\end{abstract}


An obvious significant increase $(\mathrm{P}<0.01)$ occurred in rate of foot pad thickness $1.83 \mathrm{~mm}$. in immunized group with PSC treated with direct electrical current with potential $5.77 \mathrm{~mA} / \mathrm{cm}^{2}$ for 2 min. whereas, mice immunized with PSC treated with direct current potential $11.82 \mathrm{~mA} / \mathrm{cm}^{2}$ for $2 \mathrm{~min}$. too, led to significant increases $(\mathrm{P}<0.01)$ in rate of mitotic activity of spleen and bone marrow cells, $61.8 \%, 70.1 \%$ for each, respectively.

Keywords: Echinococcus granulosus, delayed type hypersensitivity, mitotic activity.

\section{Introduction}

Cystic echinococcosis is an important cestode infection endemic in Iraq see [1]. It is potentially dangerous disease and may involve vital organs such as brain. It is primarily disease of herbivores animals, and man is infected accidentally [2]. Clinical features of the disease are highly variable and depend on organs involved, size of cysts and their sites within the effected organ, complications caused by rupture of cysts, and subsequent immunologic reaction [3].

Hypersensitivity reactions are divided into two major categories, the first category (I,II,III) is antibody mediated and, as the term immediate hypersensitivity reaction. The second major category of hypersensitivity reaction is mediated largely by $\mathrm{T}$ - cells with consequent involvement of monocytes and is appropriately termed cell mediated immunity (CMI) [4].

DTH is most seriously manifested when antigens are trapped in macrophage and can't be cleared. T- cells then stimulated to elaborate cytokines which mediate a range of inflammatory responses [5].

It well be known, that all the blood cells originate from a common stem cells by haemapoiesis, the proliferation and maturation of precoursor cells in the bone marrow are stimulated by cytokines [6]. On the other hand, mitogens have been identified that selectively stimulate either B- or T- cell populations, several sugar-binding proteins called lactins including concanavalin-A (CON-A) and phytohemagglutinin (PHA) are very effective $\mathrm{T}$ - cell mitogens [4]. However, the proportion of $\mathrm{CD}^{+}$cell markedly increased in CON-A cultures containing PSC. Furthermore, when spleen cells were co-cultured with PSC alone, marked increase in the proportion of $\mathrm{CD}^{+}$cells as well as $\mathrm{B}^{+} 2^{+}$cells [7], which demonstrates that the PSC itself stimulates polyclonally lymphocytes in vitro in normal mice [8].

There is evidence that low voltage direct current (less than 10v) [9] is bactericidal and parasitocidal in vitro $[10,11,12]$ and in vivo $[10,13,14]$. 
Electric current may destroy cell physiological action by altering the passage of molecules through cell membrane [15]. The complete destruction of human hydatid cyst protoscoleces by electrolysis device has also been reported [12]. The present study, an attempted to test the effected PSC treated with low voltage of direct electrical current on cellular immune response of BALB/c mice, infected with E.granulosus using DTH test in foot pad, and mitotic activity of cells obtained from the lymphoid organs spleen and bone marrow.

\section{Materials and methods}

Parasite: livers of sheep infected with E. granulosus hydatid cysts were collected from a slaughter house. They were immediately transferred to laboratory. The cysts were opened under the sterile conditions.

Electrolysis device: An electrolysis device was designed in a rectangular shape having dimension of $2 \mathrm{~cm}$ (length) $\mathrm{x} 0.26 \mathrm{~cm}$ (width) $\mathrm{x} 7 \mathrm{~cm}$ (height). Two flat carbon electrodes $2 \mathrm{xcm}$ were installed parallel to each other on the opposite side of the device, a distance of $1.72 \mathrm{~cm}$ between electrodes was selected as a potential [12].

\section{Groups}

The intervention groups: There are 2 groups of electrolysis solutions (Phosphate Buffer Saline (PBS), pH 7.2), each containing about 2000/1ml. live, freshly harvested PSC, the first group was subjected to direct electric current $2 \mathrm{v}=5.77 \mathrm{~mA} / \mathrm{cm}^{2}$ for $2 \mathrm{~min}$, the second group was subjected to $3 \mathrm{v}=$ $11.82 \mathrm{~mA} / \mathrm{cm}^{2}$ for $2 \mathrm{~min}$. too (Table 1 ).

The control group: There is one group consisting of (phosphate buffer solution $\mathrm{pH}$ 7.2) with about 2000PSC, which no current was applied.

Table (1): Injection protocol

\begin{tabular}{|c|c|c|c|}
\hline Days & Group A & Group B & Control \\
\hline 0 & $\begin{array}{c}2000 \text { PSC } \\
5.77 \mathrm{~mA} / \mathrm{cm}^{2} \text { for } \\
2 \mathrm{~min} .\end{array}$ & $\begin{array}{c}11.82 \mathrm{~mA} / \mathrm{cm}^{2} \text { for } \\
2 \mathrm{~min} .\end{array}$ & None \\
\hline 20 & \multicolumn{2}{|c|}{ Delayed type hypersensitivity test } \\
\hline 87 & \multicolumn{2}{|c|}{ Mitotic index } \\
\hline 90 & \multicolumn{2}{|c|}{} \\
\hline
\end{tabular}


Procedure: The electrolysed cell was filled with the solution (PBS, pH 7.2), containing fresh, active PSC. After setting the appropriate voltage and current intensity, the current was turned on, at the end of the exposure, the electric supply was turned off. The treated PSC were injected intraperitoneally in BALB/c mice. After 20 days all groups were injected with 2000 PSC, for each, as a challenge infection. All groups were dissected 3 months post infection.

\section{Protoscoleces antigen}

PSC antigen was prepared according to Dottorini et al., [16]. Protein was estimated according to Lowry et. al. [17]. Foot pad response to parasite antigen was applied according to Ali-Khan [18].

\section{Mitotic index}

Mitotic index in spleen and bone marrow cells were applied according to Allen et al. [19]. Briefly

- After 3 months of infection, all mice were injected intraperitoneally with $0.25 \mathrm{ml}$ of Cholchicin solution. After 1.30h. all mice were dissected. Spleen and bone marrow were removed.

- Cells of spleen and bone marrow were suspended by injecting these organs with PBS, then removed by syringe.

- The solution was centrifuged at 2000 r.pm. for $10 \mathrm{~min}$.

- The supernatant was removed and $5 \mathrm{ml}$ of hypotonic solution (potassium chloride solution) was added to precipitate and shaken slowly for $30 \mathrm{~min}$. at $37^{\circ} \mathrm{C}$.

- The tubs were centrifuged at 2000 r.pm for $5 \mathrm{~min}$.

- The supernatant was removed and added to precipitate $5 \mathrm{ml}$ of ammonium chloride solution (fixative solution) and the tubs were incubated at $4{ }^{\circ} \mathrm{C}$ for $30 \mathrm{~min}$.

- The last step was repeated for 3 times.

- $2 \mathrm{ml}$ of fixative solution were added to precipitate and incubated for 30 min. at $4{ }^{\circ} \mathrm{C}$.

- 4-5 drops of cells suspended were added to the slide and drying it by using hot plate at $50^{\circ} \mathrm{C}$ and stained with Giemsa stain and were being examined by using oil immersion of light microscope.

- The mitotic index was estimated as a follows:

$$
\text { Mitotic index }(\%)=\frac{\text { No. mitotic cells }}{\text { Total No. of cells }} \times 100
$$




\section{Statistical analysis}

Duncan's multiple range test was applied to determine significant differences between the means.

\section{Results}

In mice infected with PSC and injected with antigen (control group), the general picture appeared in obvious thickness in foot pad, represented by a swelling (edema). The response started at $3 \mathrm{~h}$. post injection, reached the peak at $3 \mathrm{~h}$. and $24 \mathrm{~h}$. post injection and started declining at $48 \mathrm{~h}$. post injection (Figure 1).

When mice were immunized with PSC by treating it with direct electrical current potentials $5.77 \mathrm{~mA} / \mathrm{cm}^{2}$ for $2 \mathrm{~min}$. and $11.82 \mathrm{~mA} / \mathrm{cm}^{2}$ for 2min. too (group A and B, respectively), more same response was observed in the immunized groups, it reached the peak at 24h. post injection.

In general, the response in the foot pad was significantly higher $(\mathrm{P}<0.01)$ in the immunized groups, when compared with control group. (Table 2).

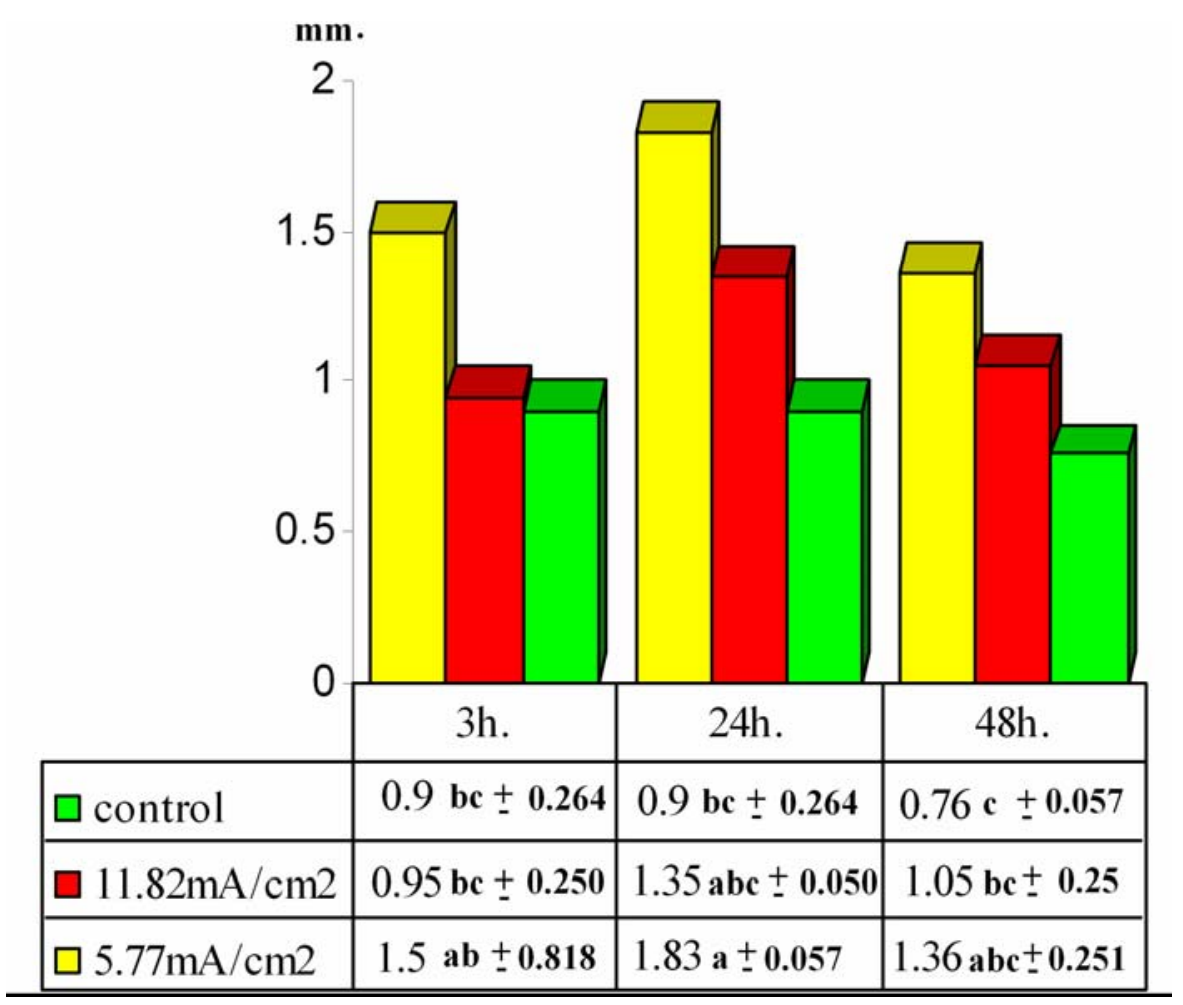

Figure (1): The effect of PSC treated with direct electric current on foot pad thickness, in mice infected with $E$. granulosus, after injection with antigen. 
Table (2): average of foot pad thickness between different groups and times.

\begin{tabular}{|l|c|c|c|}
\hline \multicolumn{1}{|c|}{ Groups } & Average $*$ & Times & Average $* *$ \\
\hline Control & $0.85 \mathrm{a}$ & $3 \mathrm{~h}$. & $1.11 \mathrm{a}$ \\
\hline $11.82 \mathrm{~mA} / \mathrm{cm}^{2}$ & $1.11 \mathrm{~b}$ & $24 \mathrm{~h}$. & $1.36 \mathrm{a}$ \\
\hline $5.77 \mathrm{~mA} / \mathrm{cm}^{2}$ & $1.56 \mathrm{a}$ & $48 \mathrm{~h}$. & $1.06 \mathrm{a}$ \\
\hline
\end{tabular}

* average of foot pad thickness between different groups.

** average of foot pad thickness between different times.

The rate of mitotic activity of spleen and bone marrow cells in immunized groups are shown in figure 2.

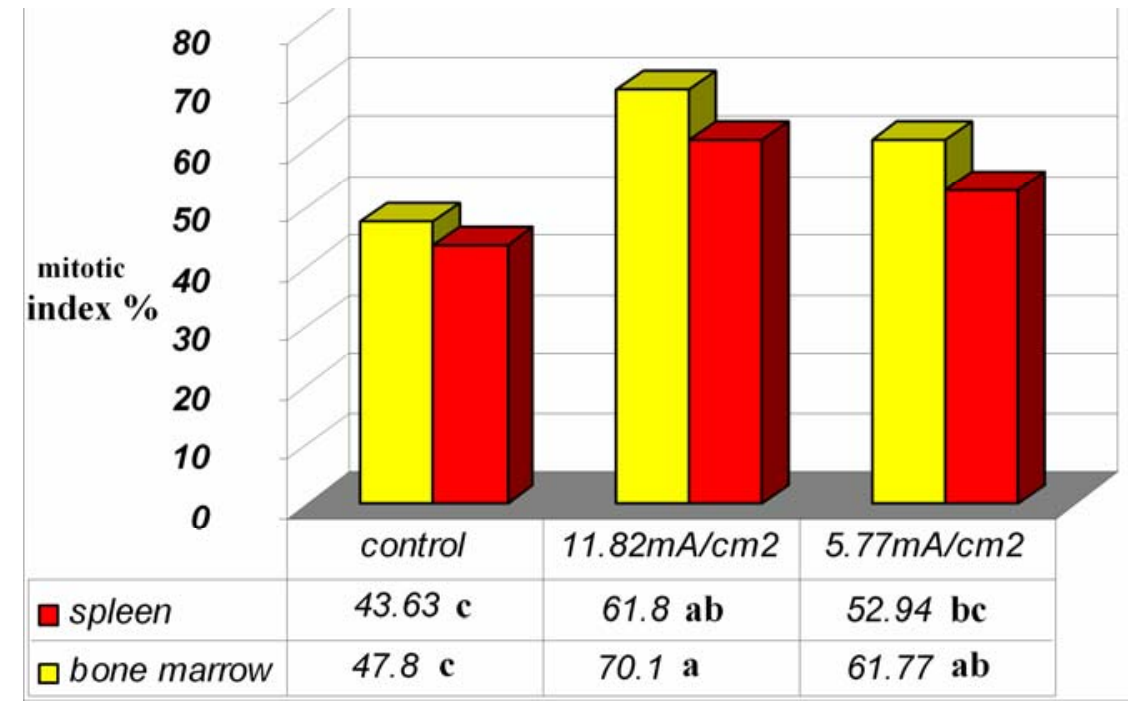

Figure (2): The percentage of mitotic activity of immunized groups in comparison with the control group

In general, it is obvious from figure (2) that mitotic index was significantly higher $(\mathrm{P}<0.01)$ in immunized groups with PSC treated with direct electrical current, compared to the control group. At most, the highest values of mitotic activity of spleen and bone marrow cells were in immunized group infected with PSC treated with direct current potential $11.82 \mathrm{~mA} / \mathrm{cm}^{2}$. (Table 3).

Table (4): average of foot pad thickness between different groups and times.

\begin{tabular}{|l|c|c|c|}
\hline \multicolumn{1}{|c|}{ Groups } & Average * & Organ & Average ** \\
\cline { 1 - 2 } Control & $47.34 \mathrm{c}$ & Spleen & $52.82 \mathrm{~b}$ \\
\cline { 1 - 2 } $11.82 \mathrm{~mA} / \mathrm{cm}^{2}$ & $65.95 \mathrm{a}$ & \multirow{2}{*}{ Bone marrow } & $59.37 \mathrm{a}$ \\
\hline $5.77 \mathrm{~mA} / \mathrm{cm}^{2}$ & $57.35 \mathrm{~b}$ & \\
\hline
\end{tabular}

* average of mitotic activity of lymphoid organ cells between different groups.

** average of mitotic activity between different organs. 


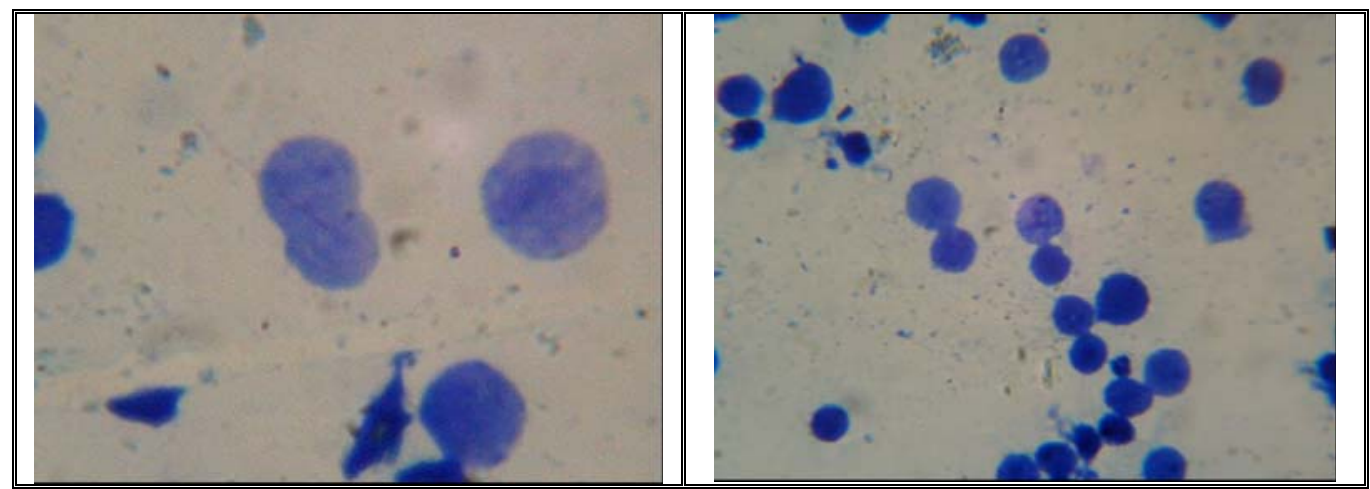

Figure (3): Photographic image Figure (4): Photographic image explain mitotic activity of splenocytes of mice immunized with PSCs treated with direct electrical current potential $\mathbf{1 1 . 8 2}$ $\mathrm{mA} / \mathrm{cm}^{2}$ for $2 \mathrm{~min}$.(1500X). explain mitotic activity of bone marrow cells of mice immunized with PSCs treated with direct electrical current potential $11.82 \quad \mathrm{~mA} / \mathrm{cm}^{2}$ for $2 \min .(1000 \mathrm{X})$.

\section{Discussion}

Cellular immune response was studied in albino mice injected with PSC treated with direct electrical current, using DTH test and mitotic activity of cells obtained from some lymphoid organs.

In the present study, the response occurred $3 \mathrm{~h}$. after sensitization with PSC antigen, reached the peak at 24h., and started declining at $48 \mathrm{~h}$. after sensitization, In fact, biological membranes transport groups of ions and polar molecules that can maintain potentials and electrostatic charges, and the integrity of the cell membrane in related to these effects $[15,20]$. The highest inflammatory response in immunized groups, may be occurred by ability of PSC treated with direct electrical current to increased of immune responses and evoke high levels of memory cells led to increased of CMI response represented by DTH in foot pad thickness which continued 48h. post sensitization. Ali-Khan [21] obtained maximum response in the foot pad at 3h. after sensitization with antigens of E. multilocularis and decline at 48h. after sensitization. Similar observations were reported (1993) by Kivity et.al. [22] as they noticed an elevation at times 4,8 and $24 \mathrm{~h}$. after antigen injection.

When mice immunized with PSC treated with direct electrical current, revealed an activation of cellular immune response, expressed by an elevation of mitotic activity in immunized groups, especially when PSC treated with direct electrical current potential $11.82 \mathrm{~mA} / \mathrm{cm}^{2}$. This may by 
attributed to the mitogenic effect of the treated PSC by direct electrical current on $\mathrm{T}$ and $\mathrm{B}$ lymphocytes in spleen and stimulation of the lymphoreticular system and activation of CMI. There is evidence that the PSC itself stimulates polyclonally lymphocytes in vitro in normal mice [8].

On the other hand, an increase in the spleen weight and organ index, were obtained in mice injected with treated PSC in comparison with the control group. This elevation in mitotic activity is in agreement with the results of Kizaki et. al. [7] it seems that, increase in proportion of $\mathrm{CD}^{+}$cells when spleen cells were co-cultured with PSC.

From the above mentioned results, it may be concluded that the PSC treated with low voltages of direct electrical currents, can stimulate cellular immune responses represented by DTH and mitotic activity, in mice infected with PSC of E. granulosus.

\section{Acknowledgment}

I would like to thank the engineer Aziz M. Hussein for assistance in designing the electrolysis device, and Dr. Salime H. Anter for statistical analysis.

\section{References}

1) AL-Sakee H. M. A., M.Sc. Thesis, College of Science, University of Baghdad (2001). (In Arabic).

2) Bayraktar M. R., Mehmet N. and Durmaz R., Turkiye Parazitoloji Dergisi, 29(3): 167-170 (2005).

3) Torcal J., Navrrozorraquino M., Lozano R., Iarrad L., Salines S. J. and Pastor J., Clin. Exp. Immunol., 106(2): 317-322 (1996).

4) Benjamini E., Coico R. and Sunshine G., "Immunology a Short Course" $4^{\text {th }}$ ed. Liss, Inc, USA (2000).

5) Roitt I., Brostoff T. and Male D., "Immunology" $6^{\text {th }}$ ed. Harcourt Publishers Limited. UK (2001).

6) Abbas A. K., Lichtman A. H. and Pober J. S., "Cellular and Molecular Immunology" $2^{\text {nd }}$ ed. W. B. Saunders Company, USA (1994).

7) Kizaki T., Ishige M., Binggan W., Day N. K., Good R. A. and Onoe K., Immunology. 79: 412-417 (1993). 
8) Kizaki T., Kobayashi S., Ogasawara K., Day N. K., Good R. A. and Onoe K., J.Immunol., 147: 1659 (1991).

9) Kalinowski D. P., Edsberg L. E., Hewson R. A., Johnson R. H. and Brogan M. S., J. Am. Ped. Med. Assoc., 94(6):565-572 (2004).

10) Hejazi H. and Dalimi A., Ann. Trop. Med. Parasitol., 98(1):37-42 (2004).

11) Izadpanah A. In: "International Hydatidology Congress" $18^{\text {th }}$ ed. Lisbon, Portugal. (1997).

12) Dalimi A., Ghasemikhan R. and Malayeri B. H. Exp. Parasitol., 109: 237-240 (2005).

13) Sharquie K. E., Al-Hamamy H., El-Yassin D. J. Dermatol., 25 (4): 234237 (1998).

14) Kloth L. C., The International Journal of Lower Extremity Wounds. 4 (1): 23-44 (2005).

15) Kilbane J. J. and Bielaga B. A., Biotechniques. 10: 254-365 (1991).

16) Dottorini S., Sparvoli M., Bellucci C. and Magnini M., Ann. Trop. Med. Parasitol., 74: 43-49 (1985).

17) Lowry O. H., Rosebrough N. J., Farr A. L. and Randall R. J., J. Biol. Chem., 193: 265-275 (1951).

18) Ali-Khan Z., Z. Parasite. J., 58: 47-54(1978).

19) Allen J. W., Shuller C. F., Mendes R. W. and Latt S. A., Cytogenetics., 18: 231-237 (1977).

20) McLaughlin S., Annual Review of Biophysics and Biophysical Chemistry., 18: 113-136 (1989).

21) Ali-Khan Z., Exp. Parasitol., 46: 157-165 (1978).

22) Kivity S., Heno N., Greif Z., Fireman E. and Topilsky N., Ann. Aller., 71 (3): 247-250 (1993).

23) Ali-Khan Z., J. Parasitol., 60 (2): 236-242 (1974). 